\title{
MATERIALITY OF RELIGION: RELIGION-RELATED ARTEFACTS IN ESTONIAN ARCHAEOLOGICAL COLLECTIONS
}

\author{
Tõnno Jonuks, Ester Oras, Kristiina Johanson
}

\begin{abstract}
In the following, an overview will be given about the progress of a three-year project, the purpose of which was to map and study religion-related objects in Estonian archaeology collections and to discuss the terminology for the archaeology of religion. As a result, a database has been created, consisting of descriptions of over 2000 objects across Estonia, which can be related, one way or another, with religion. An additional outcome of the project is a glossary of the main religion-related terms, which aims at encouraging scholars to define or describe the definitions that are employed in their studies, and especially at helping them to distinguish between different terms utilised.
\end{abstract}

Keywords: archaeology of religion, material culture, terminology

\section{INTRODUCTION}

Archaeologists' interest towards religion has a long-term history. The relevance of the topic and approaches to these issues have changed over time and developed in accordance with the main theoretical schools, evolution of methods and general interests of archaeologists. Often enough, the material is approached through site-specific or narrower material cultural corpus. More abstract questions about the concept of religious materiality and the focus on terminology are the results of more recent scholarly work. However, these questions have gained very little attention in Estonian archaeology. This situation initiated the project Materiality of Religion: Religious Artefacts in Estonian Archaeological Collections (ETF 8956), which was kindly agreed to be funded by the Estonian Science Foundation. Our aim was to map religion-related objects and discuss the relevant terminology based on Estonian archaeological material. These two fields have been studied to a lesser extent in Estonia; yet, in the near future, they might form some of the most crucial research problems in the archaeology of religion. In the following, we will provide a brief overview of the general development of the archaeology of religion and its main traditions in Estonian scholarship, and the main results of our research project with a special focus 
on terminology and evidence of religious materialities in Estonian archaeological collections.

\section{ARCHAEOLOGY OF RELIGION: A BRIEF OVERVIEW}

Archaeologists have always been interested in religion. Although approaches have changed since the very first excavations in the Near East during the 19 th century, it has often been one of the key issues. Scholars studying past religions have witnessed various traditions of handling their material. In the very beginning, archaeology had mainly a technical role, offering new sources and finds that were interpreted within mythological frameworks. Interestingly enough, such an enthusiastic tradition, in which finds were fitted into mythological narratives, was influential not only in the Near East and Mediterranean countries, but literally everywhere in Europe. In Eastern Europe, where a rich written material about mythology was not present, folklore was raised to that importance (e.g. Gimbutas 1974) and thus archaeological finds were interpreted on the basis of narratives from considerably later oral tradition.

This optimistic approach got an offensive reaction from the New Archaeology (Hawkes 1954) and for decades religion was not considered to be a proper and serious subject for archaeologists. Nevertheless, as it had been recognised widely, religion played a crucial part in the lives of past people and thus religion as a subject still emerged from time to time. In those cases rather the old traditions were followed, in which the narrative (be it a mythological text or a folk story) formed the general frame. It all changed in the late 1980s, during the period of post-processual archaeology (e.g. Garwood et al. 1991; Renfrew 1994 as the first milestones), when the interpretations made by archaeologists themselves started to be highlighted. This created a new framework, which was more independent of written or spoken narratives and relied on archaeological data. It took almost a decade until a real explosion in the field happened in the 2000s. Since then multiple studies have been published and a new concept the archaeology of religion - has emerged. Multiple conferences have been held (e.g. Garwood et al. 1991; Andrén et al. 2006), studies have been published (e.g. Insoll 2001, 2004a; Kyriakidis 2007; Fogelin 2008), first textbooks have been written (Insoll 2004a; Wesler 2012) and a massive handbook concluding the present theories and approaches has been compiled (Insoll 2011b). 


\section{RELIGION AND MATERIAL CULTURE}

Even though the leading theorists have not often regarded religion as an appropriate academic field of archaeology, there have always been attempts to interpret past beliefs. One of the reasons behind these attempts has included finds (figurines, pendants, artefacts with mystical and unknown inscriptions, etc.) that, by common knowledge, are associated with religion. A clear trend can be followed, in which mainly the attractive figurines, human sculptures in particular, have dominated in archaeological interpretations, while more common and thus tedious finds have remained somewhere in the background. A well-known example of the tendency to prefer attractive finds in interpretations is the treatment of the Scandinavian Bronze Age religion, which probably brings the Trundholm sun-chariot before the eyes of most readers. Despite a few analogies with rock-carvings or razors, in which the sun and horse appear together, it is a unique find, which still largely shapes our approach to the religion of the entire period.

The desire for the attractive and exotic finds, something 'different', can be followed already from the very early studies of religion and the critique of this approach is nearly as old. It can be observed in several cases. The study of sacred kingship would be the best known example of how an exotic concept of a social system has attracted scholarly interest and how its critique has emerged (Rowlands 2004 and references therein). The concept of associating appealing, yet also odd finds with religion can possibly be considered as universal, which is best expressed in the well-known joke about archaeologists having trouble with interpreting objects - if nothing else comes to mind, it must be religious, cultic or ritual.

Besides the problematic utilisation of actual archaeological finds, the term 'materiality' itself has also been interpreted vaguely. Various phenomena have been labelled with it, from archaeological finds to monuments and sites and even to the landscape itself (e.g. Droogan 2012). Preference of landscape indicates the emergence of a more general trend in studying religions and in many regions or periods landscape is the main source. The aforementioned 'attractiveness' has a certain role here because scholars tend to choose more charismatic and thus seemingly more informative examples as their source material. Two extreme examples can be provided in this connection. First, we could think about the richness of Neolithic figurines in south-eastern Europe, where most of the studies about religion are based on sculptures (e.g. Gimbutas 1974; Biehl 1996; Chapman 2000). On the contrary, we rarely find studies based on finds from the British Isles; the research of prehistoric religion there is based mainly on monuments and landscape analyses (e.g. Bradley 1998; Edmonds 1999; Pollard 
2009). Such a choice of sources emphasises or overemphasises some sides of past religions and leaves others unstudied.

The past few years have witnessed a rising interest towards the materiality of religion by archaeologists but even more by the anthropologists of religion (e.g. Fogelin 2008; Insoll 2009; Morgan 2010; Engelke 2011). Along with the discussions about the agency, the studies of material culture have acquired a new perspective and since then religious and symbolic meanings have often been debated. Still, following the aforementioned attractiveness, archaeologists have often chosen figurines as an example of the materiality of religion (e.g. Meskell 2004). Besides figurines, another clear topic is the tendency to set an emphasis on power systems. It is common for many periods and regions to talk about the religiosity of the nobility, chiefs, etc., and attempts to focus on common people are rather recent (see, e.g., Hansen 2006; Hukantaival 2007). This partly seems to be a matter of choice for scholars, while at the same time the religiosity of the nobility is better represented and objects connected with them seem to be more explicit.

Another topic, closely related to the aforesaid - the question of termino-logy - has emerged as well. How to label religion-related artefacts and what sort of terms should we use at all while discussing past religions? In studies so far it is common that different terms have been used, while too often inconsistencies manifest themselves. If we look at the most widely applied terms, such as 'animism', 'magical', 'ritual', etc., we can see that they are used in such a wide array of contexts that the words are already losing their content. Scholars have often avoided defining or interpreting the terms themselves and usually some wide and universal definition is used. Such a practice has resulted in the misuse of terms and thus the same phenomenon can appear in very different contexts. As for one solution, each author should define or describe how they understand the concepts they use, which is partly necessary for the readers to understand why the terms have been chosen, and partly also for the authors themselves to realise what each term actually means and thus to avoid empty labels, the meaning of which remains obscure (cf. also Insoll 2004a; Kaliff 2005).

\section{ARCHAEOLOGY OF RELIGION IN ESTONIA}

While the previous sections were striving towards the generalisation of a wider context, the situation with studying past religions in Estonia is slightly different. Due to various historical reasons religion was never a systematic field of study for archaeologists until the 21st century. The very first archaeologists from the 19th century focused mainly on stone graves as the richest monuments in Estonia. For the archaeologists from the beginning of the 20th century it 
was more important to study 'the history of Estonians' and thus hillforts and Stone Age sites were added to the previous selection. As at the same time folklorists offered their own narrative view about the past religions, archaeologists were satisfied with that and thus there was no need for the archaeological approach. During the second part of the 20th century, within the frame of scientific atheism, religion did not become a special field of interest and only single publications touched upon this field (e.g. Jaanits 1961; Tamla 1985). As a by-product, religion was used for interpretation in several contexts (e.g. numerous small-scale studies by Vello Lõugas), but especially in interpreting graves and cemeteries (e.g. Valk 1994; 2001 [1999]). Following the more general trends in Western and Northern Europe, the landscape has attracted the interest of archaeologists since the 1990s, when religion first appeared as a specific field in Estonian archaeology (Lang 1999; Vedru 2011; Jonuks 2007).

In a broader picture archaeological finds, either more or less related to religion, were used in single publications only. In those cases a careful selection of artefacts, such as cross pendants and tooth pendants in particular, served as illustrations for a general frame created by other disciplines, e.g. folkloristics or ethnology. Still it must be noted that, despite a few examples, neither folklorists nor ethnologists have had any systematic interest in artefacts. For example, in the course of folkloristic fieldwork on the Island of Saaremaa in the 1970s, local people offered to the students stone axes, which they called thunderbolts, but the latter were not interested (Mare Kõiva, pers. comm.). The approach has changed during the past few years and artefacts associated with religion have been more involved in discussions (e.g. Jets 2001; Johanson 2009; Oras 2010; Jonuks et al. 2010; Jonuks 2013).

This traditional situation, in which artefacts have rarely been used in the interpretations about religion, has created an extensive corpus of sources for past religions that has not been studied, and despite a few attractive examples (like figurines from Neolithic hunter-gatherer sites) has been left in storages. It was namely the lack of knowledge about the finds that have been scattered in different archaeological collections all around Estonia that created the necessity for a more systematic study.

\section{THE DATABASE}

The first purpose of the project was to study archaeological collections, map finds and create a database of artefacts that could be associated with religion. The first and most crucial question was of course: What is related to religion? How can we find, verify and define religion-related objects? It is widely known that in certain circumstances and depending on the context everything can 
be connected to religion, but that was not a solution suitable for us. Thus a clear danger existed to either tumble into the same trap described above and focus on attractive or odd finds only, or fall into the other extreme and regard everything as potentially religion-related, thus stating nothing really. Some colleagues have even asked: Are those the beautiful things? - referring to the same concept of attractive items that have mostly been favoured in interpreting religion. As pointed out above, the usage of 'beautiful' things could afford us a one-sided picture based on exceptional artefacts; it was decided to have a broader view and involve the 'boring' finds to a greater extent. The latter gives us an opportunity to study and see a more conventional religious behaviour than single attractive finds permit. The mission was motivated by the fact that Estonian archaeological material is rather poor in really attractive finds. In general, Estonian archaeological collections are smaller than their counterparts in Western Europe, which made the grandiose aim - to go through all archaeology collections - possible in the first place.

But still, the question remains: How to recognise religion-related objects? First of all, the preference of the term 'religion-related objects' over 'sacred objects' needs to be explained. The latter has been favoured in analogous museological studies, in which the term has been directly associated with official religions (e.g. Brooks 2012). 'Religion-related' objects include artefacts that are more loosely connected with religion, like pieces of lime, melted together with human bones and teeth, but also grave goods from a funeral pyre. These could help to better understand the cremation process, as well as ritual activity and, in the end, also the wider religious background.

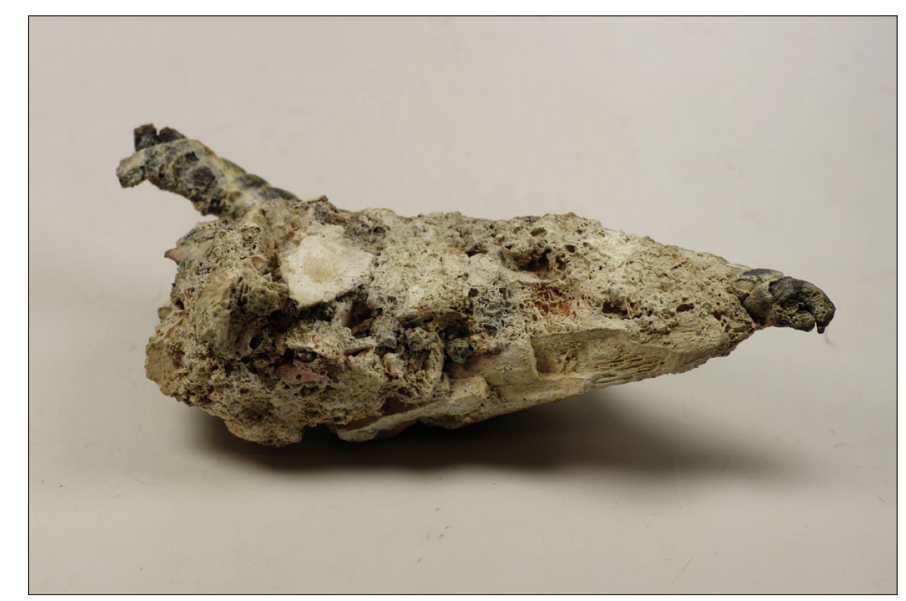

Figure 1. Melted lime from Türsamäe stone grave together with pieces of human bones and a bronze ornament (AI 2012 I 34). Photo by Tõnno Jonuks 2013. 


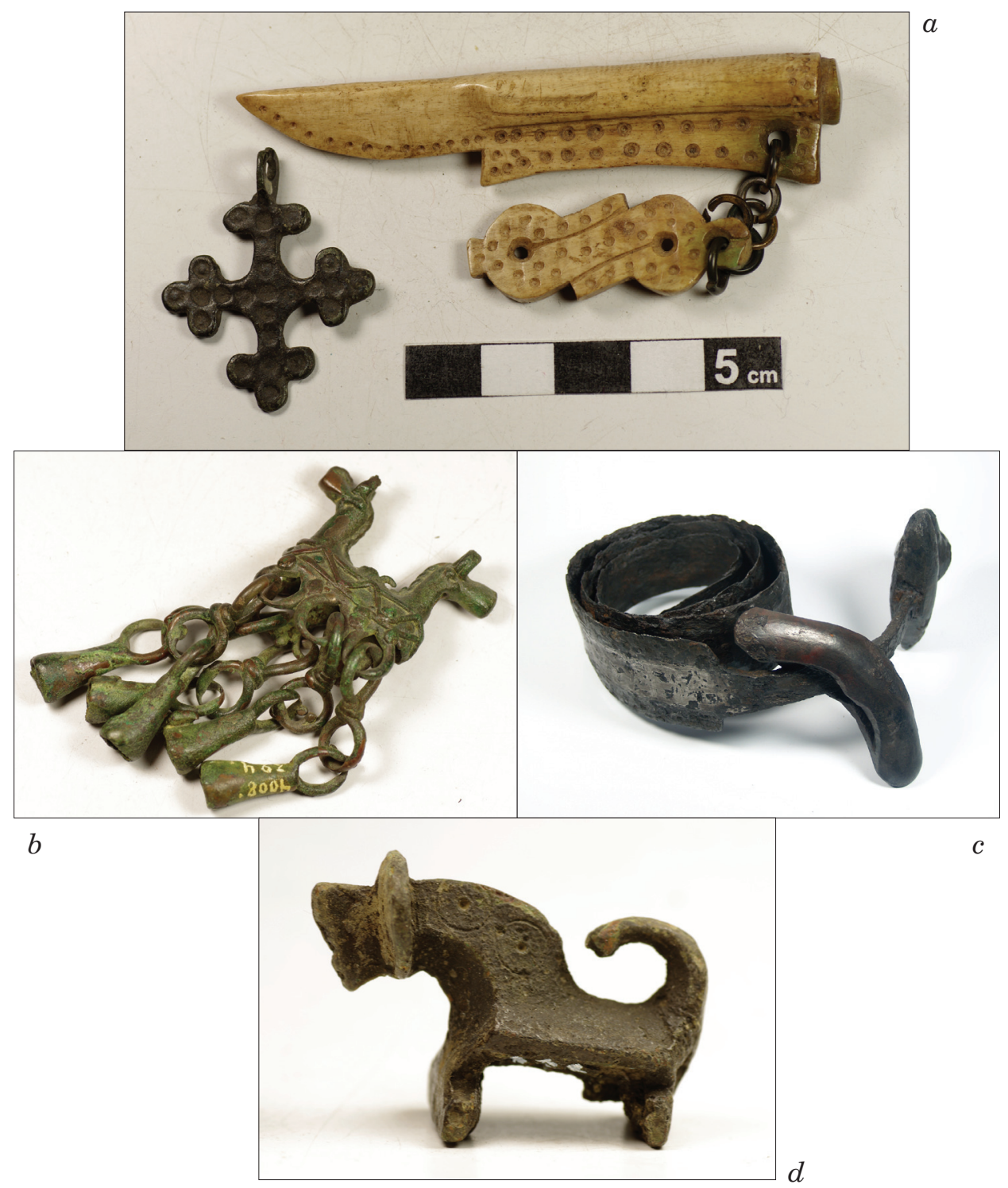

Figure 2. A selection of artefacts, the form of which is associated with religion, mythology and /or ritual: a) a cross pendant and a pendant of sheathed knife made of antler (AI 3578: 1766); b) a double-headed horse (AI 4008: 324); c) a sword bent in spiral form (AM A 580: 2020) and d) a dog or a horse figurine (AM A 554: 777). Photos by Tõnno Jonuks 2013.

Two main criteria were chosen for the selection: the form and the context. According to the former, the shape of the object was derived from religious ideas. As a classical example, a pendant or a figurine can be mentioned here, the form of which directly originates from beliefs, mythology, cult, etc. Other objects, like 
deliberately broken or damaged grave goods, were classified according to this as well, and here again the modified shape of the object, like a sword turned into a spiral, was decisive. The category of form also included symbols that had been used for the decoration of jewellery. Although most of the symbolism seems to be too uniform and universal to carry any specific (religious) meaning, some symbols (the cross and its derivatives in particular) seem to carry a purposeful belief. At the same time several objects, which may have had a symbolical role, like axes, swords, etc., were excluded. In the studies of the Bronze Age Scandinavia the symbolic objects (swords, razors) play a crucial role (see Kristiansen \& Larsson 2005; Kaul 1998); however, it has not been possible to follow this in Estonia.

Another criterion - the context - is even more conditional. There are only single cases known from the entire prehistory of Estonia, in which deposits have been interpreted as sacrificed (see Oras 2010), and are thus included in a clear religious context. Rare examples are known in which finds have been gathered from particular holy places known from folk religion, like the surroundings of sacred stones or trees (Jonuks 2011). Based on context, several objects were recorded that did not (chronologically) 'fit' into their finding context; one of the reasons for that may have been the association of the finds with religion or magic. A classic example is the Stone Age axes and arrowheads from the Late Iron Age and medieval contexts (Johanson 2009). Most of the objects that were classified as 'religious' according to the context do not have any special external features and it was the context, or the place, that made those particular objects different and special. As an example, nails that were found from the trunk of the Ülendi offering linden (AI 2679) may be mentioned. According to oral tradition, nails were hammered into the trunk to hold ribbons that were carrying gleet from tumours, and so the tree was functioning as a scapegoat. Without oral tradition those nails would have nothing to do with religion. Oral tradition also initiated the recording of several magical or healing objects. These are usually the most ordinary artefacts - coins, fossils, stone axes, strike-a-lights, etc. It is only the oral tradition, mostly recorded at the beginning of the 20th century, which says that these were really used for magical or healing purposes.

The latter will raise another complex of questions concerned with the sources of the past religions. Differently from the rest of Europe, Estonia and Eastern Baltic in general have an influential tradition of using oral tradition from the 19th and 20th centuries for interpreting religion from the distant past (e.g. Kulmar 1992). Due to several historical processes, oral tradition gained its importance already in the 19th century and as archaeologists did not participate actively in the discussions about religion, the importance of folk tales became essential. As traditional written sources from the Baltic region, like medieval chronicles, 

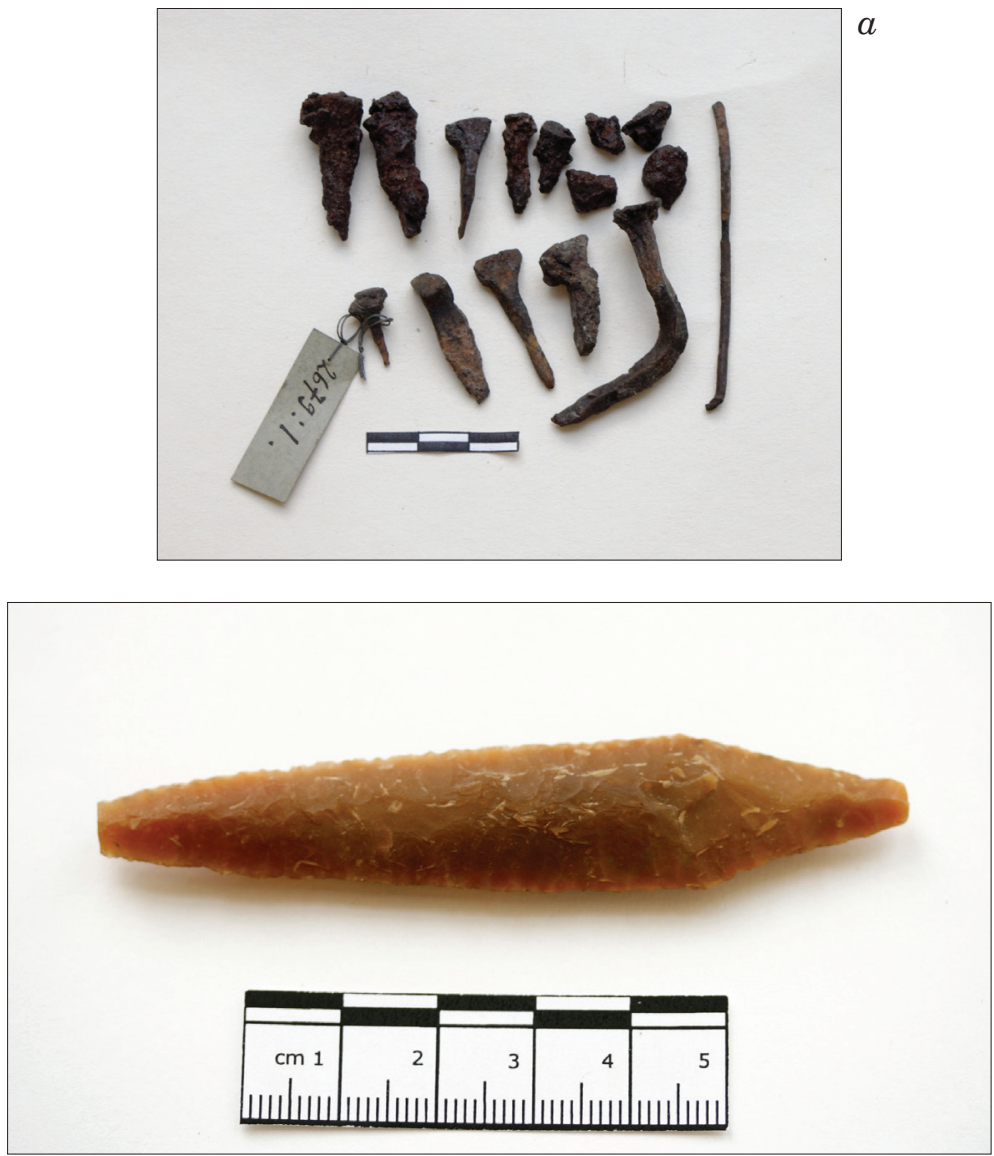

Figure 3. A selection of finds, the religious meaning of which derives from the find context: a) iron nails (AI 2679, photo by Tuuli Kurisoo 2013) found from the tree trunk of Ülendi sacred tree, and b) a flint arrowhead found from the Early Modern context from Tartu (TM A 50: 449, photo by Arvi Haak 2010).

contribute little, if anything at all, to the understanding of past religions, then folk tradition along with the ethnographic analogies of the Finno-Ugric tribes in Russia formed the main background, within which the meaning was given to archaeological finds. As such analogies came from different temporal and cultural contexts, it was only natural that many archaeological objects that did not fit with examples from living cultures, were overlooked.

It is clear without saying that there are no objective criteria to suggest that some things are more religious than others. So it must be remembered that the artefacts recorded during the project were selected by the team and decisions 
were made according to our knowledge and backgrounds. Still, the choice was made on the broadest possible level, keeping in mind that the collection of data should be competent and suitable also for the future studies. Due to this, also exotic objects (e.g. rock crystal) or artefacts of unknown purpose (e.g. ceramic things) were included.
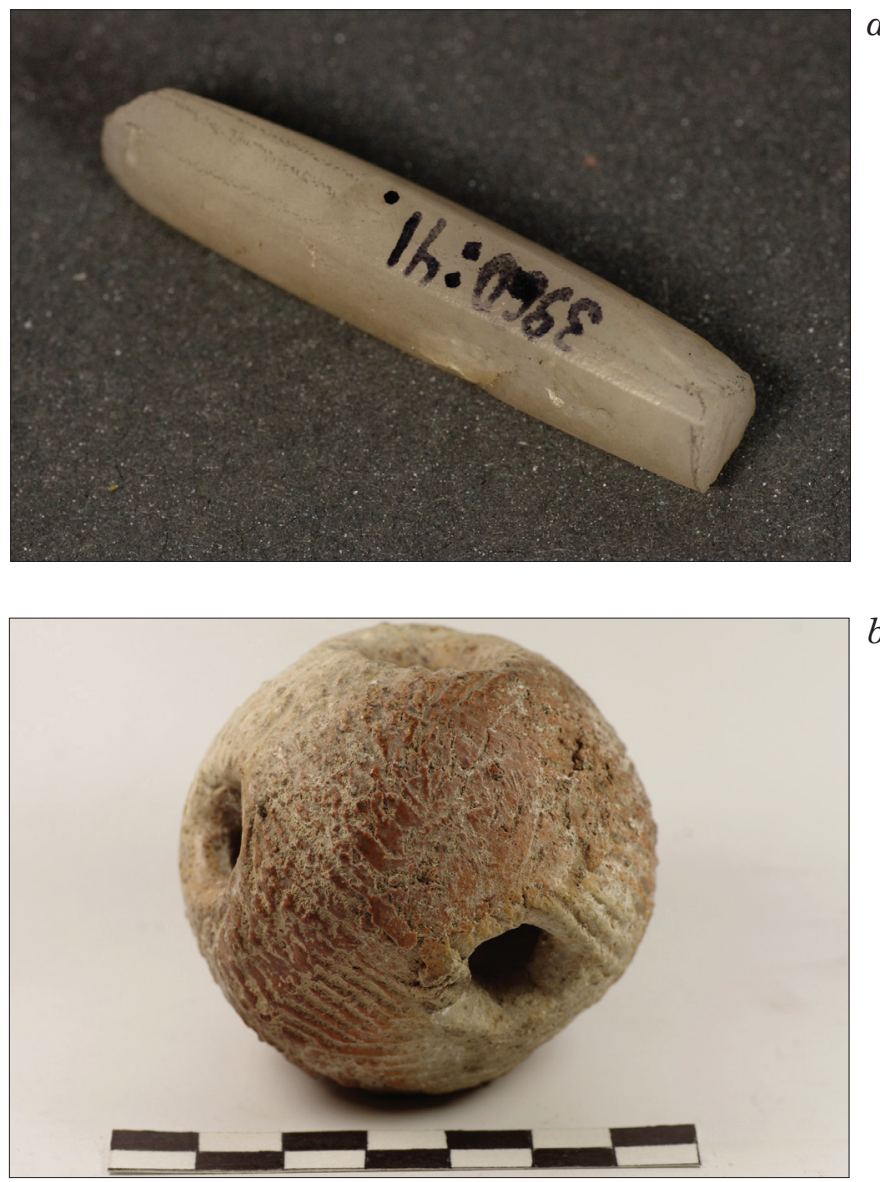

Figure 4. a) A piece of a rock crystal (AI 3960: 41) from Tamula Neolithic fisher-hunter settlement and cemetery site and b) a ceramic 'object' of unknown purpose (AI 4510). Photos by Tõnno Jonuks 2013. 


\section{TERMINOLOGY}

Besides the mapping of religion-related artefacts and creating of a relevant database, another major aim of the research grant was to elaborate on the terms that archaeologists use in their research on past religions. We created a short glossary of most relevant and frequently used terms in the context of northern Europe, especially Baltic archaeology, including words like: cosmology/ cosmogony, cult, magic, myth, sacrifice and/or offering, sacred/holy/numinous, religion, ritual, totem, votive. This list is by no means exhaustive, but reflects the main interests and problems that we tackle in our own research on the archaeology of religion. The following terminology discussion is certainly not a detailed overview of all the problems and solutions within the archaeology of religion. It rather aims to exemplify some of the issues that become evident when focusing on the questions of terminology and choice of words used in this field of study. In order to gain a broader perspective on terminology-related discussions, a conference session Archaeology of Religion: Thinking about Terminology was also organised at the 34th Annual Conference of the Theoretical Archaeology Group meeting in Liverpool in December 2012, as part of the research grant.

The classical starting point for the studies of religion, be it present or past, is the question of definition. Naturally in the context of our grant project, we should offer a definition to 'religion'. As follows from the above explanations for religious artefacts, the task is definitely not easy and can even be considered a dead end. So, instead of stating in the manner of Harvey Whitehouse (2004: 230), "religion is whatever we agree to say it is", we could try to understand religion in the framework of and through the opposition to other terms, which have been used in seemingly similar contexts. The first item to look into would be the distinction between religion and ritual. Such discussions have a long-term history in anthropology and religious studies. While the earlier scholars tried to provide universal definitions of these terms (cf., e.g., classical works by Tylor 1929 [1871]; Durkheim 2002 [1915]; Firth 1951; Geertz 2002 [1966]; Turner 1967), then later discussions debated about the usefulness and applicability of such endeavours (Asad 1983, 2002; Goody 1961; Lewis 1980). It is clear that neither religion nor ritual is easily defined and each attempt to provide universal explanations for those abstract concepts includes biases and hindrances. The implication of these discussions for archaeology is that religion as a very wide and abstract category is often left entirely undefined, and the concept of ritual(s) as more materiality-related and therefore visible to archaeologists is used instead (cf. Insoll 2004a; 2004b). The latter is most commonly inspired by the now classical works about the concept of ritualisation by Bell $(1992 ; 1997)$. When talking about religion, plural forms, i.e., different religions 
in the past and present, are used in order to emphasise the multifaceted nature of religious worldviews depending on spatial and temporal contexts (cf. articles and case studies in Insoll 2011b; for Estonian material see Jonuks 2005; 2009).

The main problem that haunts the use of the term 'ritual' is that, being indeed most wide and archaeologically best recognisable, it can be applied to almost everything. It often seems that 'ritual' has turned out to be an umbrellaword used whenever some religious, but also ideological and social events, are involved. The examples include a range of activities from feasting, witchcraft, votive deposits, and sacred natural objects to foundation deposits, waste pits, public show-off, etc. The discussion of non-religious rituals in anthropology (cf., e.g., Moore \& Myerhoff 1977; Kertzer 1988; Connerton 1989) has certainly influenced these developments. Another debate that has unquestionably broadened the scope of the term 'ritual' in archaeology is the abandonment of strict and opposing profane $v s$. the sacred connotation of the term (e.g. Brück 1999; Bradley 2003, 2005; Insoll 2004b: 2-3). The strict division into sacred and profane, special and ordinary, is a by-product of the post-enlightenment worldview, from which the scholars find it hard to step out. As pointed out by several researchers, rituals can be practical and daily, rational and also differently interpreted and perceived by the practitioners themselves. Rituals can be ordinary, socially inspired, even daily activities just as much as they are sacred, religious and a special kind of practice.

The discussions that loosen our idea of ritual have certainly broadened our understanding of past societies and the widened scope of the concept of ritual. However, does that broadening of the concept also mean losing something from its essential quality and meaning? Even though we agree to the idea of the allencompassing nature of ritual, not every formalised, repeated, structured and prescribed act is necessarily a ritual. One can think of a family dinner and the following washing-up, personal morning routines or daily factory work. As stated by Bell $(1992 ; 1997)$ and Humphrey \& Laidlaw (1994), there must be a special quality involved, because this special inner quality turns an act into a ritual. Indeed, every act can be ritualised and in this sense all the daily might become a ritual, if a special inner qualitative change is thought to happen. However, it is exactly this qualitative change that pulls the act away from the ordinary, gives it a special meaning, becomes ritualised and turns it into a ritual. The qualitative change involves the creation of a relationship with the supernatural and it has its symbolic connotations that can be applied to the act either physically or mentally. The methodological issues, such as how archaeologists can grasp those materially and mentally applied qualitative meanings, are a topic of another larger debate. What is important here is to note that even though ritual is a much wider concept than just religion in practice, it still has an 
essential connection with religion and the supernatural. Perhaps this is also the reason why some scholars have turned their eyes back to the importance of religion when defining ritual (e.g. Garwood et al. 1991: vii; Fogelin 2007; Verhoeven 2011).

Ritual as a broad umbrella-term includes also several other terminologyrelated confusions when it comes to its subtypes and -divisions. The words that are most difficult to define and distinguish from each other, but which are commonly used in seemingly similar interpretations, are 'ritual', 'magic', 'cult', 'sacrifice' and 'offering' (with the addition of 'votive'). More than anything else, the use of those terms seems to be a matter of local scholarly traditions and geographically determined preferences.

A large area of confusion is the distinction and relation between religion and magic, and together with these the religious and magical practices as well as religious and magical artefacts. The dichotomy of magic and religion has been long discussed by historians of religion, whereas opinions have ranged from one extreme, in which magic and religion are viewed as in strict opposition with each other, to the other, in which the term magic has been regarded as a "semantic trap" and expelled from scientific circulation altogether (see more in Graf 1991: 188). The early anthropologists (Edward Spencer, Edward Burnett Tylor, James Frazer) made a clear distinction between magic and religion, seeing magic as a means to control events and religion as a way to explain events. However, the post-war intellectualists (Ian Jarvie, Jack Goody) regarded magic both as controlling events and as explaining them through attribution to magical agency, and religion as the means to explain events as well as influence them via divine intervention (see more in Cunningham 1999: 77). So, the clear-cut distinction between magic and religion was lost; however, a distinction between the magical agency and religious divination stepped in instead. For different researchers in the history of scholarship some aspects have played a more decisive role in acknowledging the presence of either magic or religion, and thus supplicative (religion) vs. manipulative (magic); symbolical (religion) vs. practical (magic); private/secret (magic) vs. public (religion) or individual (magic) vs. collective (religion) have been emphasised. However, most researchers from the 19th century onward, who deal with the topic of magic, have acknowledged the existence of grey areas; in fact, if we take the definitions and explanations as the basis, then the majority of practices seem to fall into this grey area between religion and magic. This is hardly a surprising conclusion for somebody dealing with definitions and terminology, but what is surprising is the number of researchers who still classify the artefacts they find either as magical or religious. 
So, is there a difference between magic and religion and can it be grasped? The difference apparent on a conceptual level is not so obvious when discussing practices and artefacts; for example, using a religious prayer and a so-called magical amulet simultaneously in the same practice, or using the Bible in church rituals as well as in different popular healing practices, etc. Ideas from different initial sources intertwine in popular practices and their connection with clear-cut conceptions is not real. In that sense magic and magical practices are very practical, with a specific purpose and an unambiguous outcome; they are performed individually when needed and cannot be regarded as exceptional. This in turn means that any object can have a meaning in a magical procedure, and thus be regarded as a magical item (e.g. simple nails in the offering tree). On the other hand, like in the case of rituals, in which not all repeated actions are ritualised, not every practice with a focussed purpose and an explicit outcome is magical. In line with rituals, the relationship with the supernatural must be created here as well, which in the case of magic could be called the magical state of mind (Wax \& Wax 1962), magical interpretation (e.g. Sørensen 2005), magical consciousness (Greenwood 2009), faith, or ritual sense (Bell 1992).

In this volume a detailed overview of the questions of sacrifice and offering is provided by Ester Oras. Looking at the definitions of and relations between ritual and cult, there seems to be a rather large gap between the use of these terms in religious studies and archaeology. The former tend to relate cult to non-traditional and innovative religious movements, which are often shortterm and person-related, such as the cult of emperors (cf. relevant definitions in The Concise Oxford Dictionary of World Religions (2000) and The Concise Oxford Dictionary of Archaeology (2008)). In archaeology the concept has a much wider connotation. First of all, cult is most often used as a synonym to ritual in the studies of prehistoric and protohistoric Mediterranean contexts (cf. Renfrew 1985; Barrowclough \& Malone 2007). The second larger use area is related to the cult of ancestors (Insoll 2011a), and as such has been widely applied to Estonian material as well (e.g. Lang 1999; Jonuks 2009). The third example of the utilisation of the word 'cult' is connected to different religiousrelated sites from both history and prehistory. In these cases it is noteworthy that different terminology can be applied to rather similar types of sites, e.g., for the eastern Baltic natural sites that have been used as religious sites the terms like sacred places, holy places, groves, or cult sites have been used (Tamla 1985; Vaitkevičius 2004; Jonuks 2007; Urtāns 2008). In those studies it is not always clear why one word is preferred to another and if there is any essential difference between the connotations of those specific words in the first place. It rather seems to be a matter of scholarship tradition in a particular geographical region which is decisive when it comes to choosing terminology for such a 
specific dataset. The problem might also relate to the question of language and translation: the choice of words and their related meanings in native languages are not always directly transferrable to foreign languages such as English and German (see also discussion of sacrifice and offering in Oras, this volume). Thus the choice of terminology and related meanings are also constrained and influenced by the availability of concepts in specific languages.

There are also some terms and concepts that seem to have a rather strict chronological and spatial distribution. The question of cult and its relation to Mediterranean context was already pointed out above. Another such example is the concept of shamanism. This religious world view is most commonly discussed in the studies of Stone Age religions (e.g. Lewis-Williams \& Clottes 1998) and the people living in the northern forest belt regions (Price 2001). Very seldom can we see such elaborate examples of shamanism in Bronze and Iron Age contexts (see, e.g., Randsborg 1993; Price 2002). It is rather obvious that the reason is indeed in the spread of certain religious concepts within a particular cultural and environmental context. ${ }^{1}$ However, shamanism is a good example of context-specific religion-related terminology that most likely cannot be applied to and searched for in every region and period of time. It shows a high sensitivity of utilising at least some terms when studying past religions. Another such example of geographically and temporally constrained and traditionally developed terms would be the concept of 'votive'. This term most likely derives from the Mediterranean protohistoric and historic contexts and has been used in scholarship inspired by those case studies (see the definition of 'votive' in The Concise Oxford Dictionary of Archaeology (2008); cf., e.g., Renfrew 1985; Aitchison 1988; Crawford 2004; Osborne 2004). In northern Europe Bronze or Iron Age studies the words such as 'sacrifice' or 'offering' are usually employed even if those practices in different times and regions might share several similar characteristics.

As seen in most of those examples of terms and definitions, the main inspiration for archaeologists derives from anthropology, sometimes also from the religious studies. It is a whole new topic for discussion if and to what extent such loans have been fruitful, well-argued or misused. The main difference that is always worth re-emphasising is the question of sources. The information available to ethnographers and scholars of religious studies is usually very different from that used by archaeologists. If the former can rely on direct contact and evidence from the practice-in-happening, then the latter is based on the fragmentary remains of past practices, from which some (sic!) can indeed be related to religious and ritual activities. As can be seen in the example of relating or distinguishing magic and religion, very often the material remains solely do not reflect any religious-related activity involving the object. First, we 
need ethnographic parallels or written sources in order to attain this interpretation. Second, we still lack firm arguments or direct evidence to provide final and single interpretations of something being religious. Therefore the question remains how reliable it is to borrow definitions from other social sciences if the source material is essentially different. Do we need our own, i.e., specific archaeologists' terminology and definitions for the study of religion, e.g., the network of terms for materialised religion or religious materiality? When do we have enough evidence from material remains to say that we are dealing with the same phenomena in the distant past that are described and defined in anthropology? The relevance of those questions might be best exemplified if we try to combine the source material that was under focus in our grant: objects in themselves as they lay on the shelves in museums and other research institutes.

Let us take a simple example of a cross-shaped pendant. Which religionrelated term (if any at all) should be applied to it? Is it a religious object, a ritual object, perhaps a cultic or even magical one? Or perhaps none of those? For instance, as discussed by Jonuks and Kurisoo (this volume), a cross might be interpreted as a universal decorative element (ordinary design element), a sign identifying the wearer as a Christian (religious object? or ritual object?) or a protective amulet (magical object?). Or could a cross pendant be all of those at the same time and thus blur the differences between all those terms?

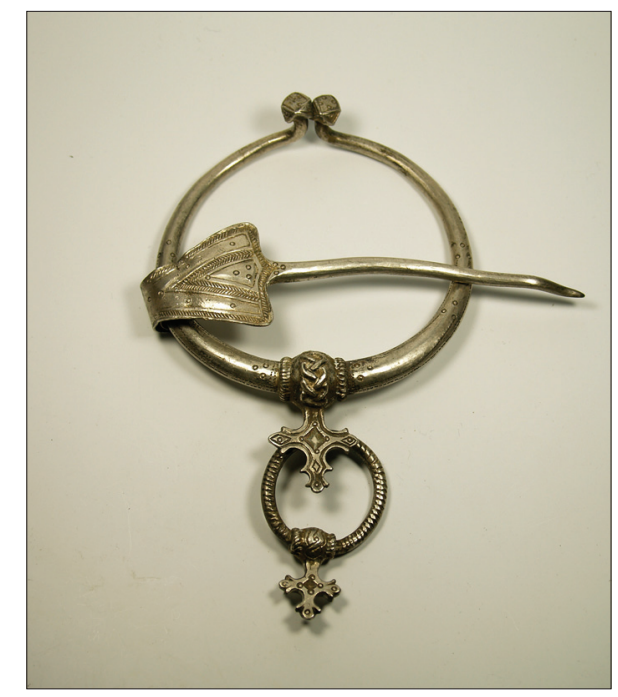

Figure 5. A silver brooch from Lagedi with two crosses (AM 1100). Was the cross a symbol of faith or prosperity? Or was it a protective amulet? Or all of those together? Photo by Tõnno Jonuks 2013. 
To decide for one and against the other, further information about its find context, related objects and sites is necessary. However, the cross-shaped pendant is, to some extent, simpler and more universally spread phenomenon, which is familiar to us even in our contemporary world. But what can we think of pendants in the shape of a human face or a knife? Are they ritual, religious, magical, shamanistic, totemic or cultic? Or do they symbolise a craftsman? A wealthy person? Or is it just a nice piece of decoration?

Choosing the right term will be even more complicated if an example comes from the religious context but not from form. An ordinary nail, hammered into a tree-trunk as mentioned earlier, can be used as a good example of this. As it is known from folklore, nails were symbols of a wish or a pray. Or, for instance, a pair of ordinary scissors, used for divination: How shall we label such objects? They are not religious or cultic by themselves as they have not been made for that purpose or stored in any special way. They are not offered either. So we possibly need to consider another type of objects - magical mediums. Magical mediums would be objects that are part of mundane material culture, can be incorporated into religious behaviour and the explicit function of which is to be a mediator between the human and the supernatural, just like scissors in the divination mediate foretelling. Or like a coin that was put on an ill part of a body, was associated with the illness and if left in a spring or on a stone, the coin as a proxy should have tied the sufferings of the body with this place.

This is where the problems of terminology lie if we deal with objects only. Without any further information about the context, spatial and temporal belonging, relationship to other objects or features, attestations of the user or parallels from historic and ethnographic record, the interpretation of the artefact cannot go any further than symbology and possible religion-relatedness. With no regard to sites, practices, and use of the object, the label 'religious object' is the widest and safest, if we agree that it is religion-related at all. However, the answer and story that it provides is also very abstract and general, and does not embrace much of the essential meaning and function of the object. Therefore, the label 'religious object' calls for a need and encourages scholars to look for parallels and comparisons from other sources, or to ask for further archaeological information that would allow to go deeper into the meaning and function of the object, i.e., to interpret it in a more nuanced and detailed way. 


\section{FUTURE PLANS}

The project has yielded over 2000 objects recorded in the database along with photos and descriptions. According to the original plan, which hopefully will succeed in the coming years, the database and a glossary of terms will be published online, with explanations in English. Apparently, there are so many single and unique objects, which are often stray finds, that only the publishing of raw data could help us to find analogies. This would also help to move further from the general term 'religious object' and find a more reasonable and detailed interpretation. The aim of the project was, first and foremost, to collect data, create an environment for future studies and map some of the most potential issues. The publishing of studies of some single items (Jonuks 2013) or groups (Oras forthcoming a; Jonuks \& Joosu 2013) has started as well. A large-scale study has already been conducted within the project about the Late Iron Age cross pendants (Kurisoo 2012; 2013) and will be extended to all Late Iron Age pendants in the coming years. An analysis has been carried out of wealth deposits in all the Eastern Baltic countries (Oras forthcoming b) and another one is in preparation about the concept of magic in archaeology and about objects possibly used for magical purposes.

Although a few publications have already been completed, the actual study of religious objects in Estonia is just about to begin and this project merely created a basis for it. Predictions for the future are never appreciated, but on the basis of the past three years some changes as compared to the previous decades can be pointed out. As was mentioned previously, the early tradition of using archaeological finds was based on either folkloristic or ethnological frame, in which only suitable examples were used as illustrations. Later on the tradition reversed and archaeological finds started to be interpreted on the basis of folklore or ethnology. Due to this, interpretations of objects are largely only humanitarian. The current trend rather points to the more important role of a scientific approach and several new methods of study have been used already or are in progress for pointing out new perspectives for object biographies.

Another methodological possibility, especially for the unattractive massmaterial, would be to apply some qualitative statistics to the material collected. A large-scale database that covers also ordinary mass finds, e.g. tooth pendants, allows us to see how this tradition has changed, what animals have been used, when they have been killed, etc. As interpretations of religion have often been based on some single objects, broader comparative analyses are necessary for many groups of finds, including pendants, fossils, lithic material from the Mesolithic and Neolithic in later contexts, etc. These are all crucial subjects when discussing religion in archaeology, but far too often scholars have based their 
analyses only on single examples and stretched that result to other contexts as well, without any particular sources.

In conclusion, as a result of our project we have only just started to grasp the multifaceted problems that need to be tackled when studying religion on its material bases. During data collection and the following interpretations, we also became increasingly aware of the difficulties of providing more detailed definitions, conceptual categorisations, meanings and functions to specific archaeological material. Thus, this project emphasises once again the importance of multi-methodological and multi-source approaches in the archaeology of religion. We have gathered a good amount of data on religious-related archaeological finds in Estonia and started to grasp the theoretical and methodological issues that emerge when doing a paralleled and comparative study of specific object types within the frame of a larger data corpus. The initial ideas presented in this overview article are just tentative results and the data gathered during this three-year period will be developed further in future projects, publications and discussions.

\section{ACKNOWLEDGEMENTS}

The authors are grateful to many colleagues in Estonia and also abroad, who have discussed the issues presented above with us and thereby helped to elaborate the whole project. We are especially thankful to the staff of the Estonian county museums and to the keepers of archaeology collections in central institutions (Tallinn University Institute of History, University of Tartu) for their help in using their collections. Without their assistance and trust this project and its future outcomes would have been impossible.

This research is supported by ETF grant 8956 Materiality of Religion: Religious Artefacts in Estonian Archaeological Collections, in collaboration with the European Union through the European Regional Development Fund (Centre of Excellence in Cultural Theory (CECT)), and SF 0030181s08.

\section{ABBREVIATIONS}

AI - collection of archaeology at the Institute of History, University of Tallinn ERA - Estonian Folklore Archives, Estonian Literary Museum TM A - collection of archaeology at the Tartu City Museum AM A - collection of archaeology at the Estonian History Museum, Tallinn 


\section{NOTE}

1 But according to the preferences of scholars in how to define the term, shamanism can appear also in Modern Age rural Europe (e.g. Ginzburg 1983), or in any temporal or spatial contexts, defined according to the neuropsychological features (e.g. Lewis-Williams \& Dowson 1988; Whitley 2005) indicating again the importance of the scholarly interpretation of the word.

\section{REFERENCES}

Aitchison, Nick B. 1988. Roman Wealth, Native Ritual: Coin Hoards within and beyond Roman Britain. World Archaeology, Vol. 20, No. 2, pp. 270-284, http://dx.doi.or g/10.1080/00438243.1988.9980072.

Andrén, Anders \& Jennbert, Kristina \& Raudvere, Catharina 2006. Old Norse Religion: Some Problems and Prospects. In: A. Andrén \& K. Jennbert \& C. Raudvere (eds.) Old Norse Religion in Long-Term Perspectives: Origins, Changes, and Interactions. Vägar till Midgård, Vol. 8. Lund: Nordic Academic Press, pp. 11-14.

Asad, Talal 1983. Anthropological Conceptions of Religion: Reflections on Geertz. Man, Vol. 18, No. 2, pp. 237-259, http://dx.doi.org/10.2307/2801433.

Asad, Talal 2002. The Construction of Religion as an Anthropological Category. In: M. Lambek (ed.) A Reader in the Anthropology of Religion. Blackwell anthologies in social and cultural anthropology, Vol. 2. Malden, MA: Blackwell Publishers, pp. 114-132.

Barrowclough, David A. \& Malone, Caroline (eds.) 2007. Cult in Context: Reconsidering Ritual in Archaeology. Oxford: Oxbow Books.

Bell, Catherine 1992. Ritual Theory, Ritual Practice. New York: Oxford University Press.

Bell, Catherine 1997. Ritual: Perspectives and Dimensions. New York: Oxford University Press.

Biehl, Peter F. 1996. Symbolic Communication Systems: Symbols on Anthropomorphic Figurines of the Neolithic and Chalcolithic from South-Eastern Europe. Journal of European Archaeology, Vol. 4, No. 1, pp. 153-176, http://dx.doi. org/10.1179/096576696800688097.

Bradley, Richard 1998. The Significance of Monuments: On the Shaping of Human Experience in Neolithic and Bronze Age Europe. London \& New York: Routledge.

Bradley, Richard 2003. A Life Less Ordinary: The Ritualization of the Domestic Sphere in Later Prehistoric Europe. Cambridge Archaeological Journal, Vol. 13, No. 1, pp. 5-23, http://dx.doi.org/10.1017/S0959774303000015.

Bradley, Richard 2005. Ritual and Domestic Life in Prehistoric Europe. London: Routledge.

Brooks, Mary M. 2012. Seeing the Sacred: Conflicting Priorities in Defining, Interpreting, and Conserving Western Sacred Artifacts. Material Religion: The Journal of Objects, Art and Belief, Vol. 8, No. 1, pp. 10-29, http://dx.doi.org/10.2752/17518 $3412 X 13286288797818$. 
Brück, Joanna 1999. Ritual and Rationality: Some Problems of Interpretation in European Archaeology. European Journal of Archaeology, Vol. 2, No. 3, pp. 313-344, doi:10.1177/146195719900200303.

Chapman, John 2000. Fragmentation in Archaeology: People, Places and Broken Objects in the Prehistory of South-Eastern Europe. London \& New York: Routledge.

Connerton, Paul 1989. How Societies Remember. Cambridge: Cambridge University Press.

Crawford, Sally 2004. Votive Deposition, Religion and the Anglo-Saxon Furnished Burial Ritual. World Archaeology, Vol. 36, No. 1, pp. 87-102, http://dx.doi.org/10.1080 /0043824042000192641.

Cunningham, Graham 1999. Religion and Magic: Approaches and Theories. New York: New York University Press.

Droogan, Julian 2012. Religion, Material Culture and Archaeology. London: Bloomsbury Academic.

Durkheim, Émile 2002 [1915]. The Elementary Forms of Religious Life. In: M. Lambek (ed.) A Reader in the Anthropology of Religion. Blackwell Anthologies in Social and Cultural Anthropology, Vol. 2. Malden, MA: Blackwell Publishing, pp. 34-49.

Edmonds, Mark 1999. Ancestral Geographies of the Neolithic: Landscape, Monuments and Memory. London \& New York: Routledge.

Engelke, Matthew 2011. Material Religion. In: R.A. Orsi (ed.) The Cambridge Companion to Religious Studies. Cambridge: Cambridge University Press, pp. 209-229.

Firth, Raymond 1951. Elements of Social Organization. London: Watts.

Fogelin, Lars 2007. The Archaeology of Religious Ritual. Annual Review of Anthropology, Vol. 36, No. 1, pp. 55-71, http://dx.doi.org/10.1146/annurev. anthro.36.081406.094425.

Fogelin, Lars (ed.) 2008. Religion, Archaeology and the Material World. Occasional Paper No. 36. Center for Archaeological Investigations. Carbondale: Southern Illinois University.

Garwood, Paul \& Jennings, David \& Skeates, Robin \& Toms, Judith (eds.) 1991. Sacred and Profane: Proceedings of a Conference on Archaeology, Ritual and Religion: Oxford 1989. Monograph, Oxford University Committee for Archaeology, Vol. 32. Oxford: Oxford University Committee for Archaeology.

Geertz, Clifford 2002 [1966]. Religion as a Cultural System. In: M. Lambek (ed.) A Reader in the Anthropology of Religion. Blackwell anthologies in social and cultural anthropology, Vol. 2. Malden, MA: Blackwell Publishing, pp. 61-82.

Gimbutas, Marija 1974. The Goddesses and Gods of Old Europe: Myths and Cult Images. London: Thames \& Hudson.

Ginzburg, Carlo 1983. The Night Battles: Witchcraft and Agrarian Cults in the Sixteenth and Seventeenth Centuries. Baltimore: Johns Hopkins University Press.

Goody, Jack 1961. Religion and Ritual: The Definitional Problem. The British Journal of Sociology, Vol. 12, No. 2, pp. 142-164, http://dx.doi.org/10.2307/586928.

Graf, Fritz 1991. Prayer and Magic in Religious Ritual. In: C.A. Faraone \& D. Obbink (eds.) Magika Hiera: Ancient Greek Magic and Religion. New York \& Oxford: Oxford University Press, pp. 188-213.

Greenwood, Susan 2009. The Anthropology of Magic. Oxford \& New York: Berg. 
Hansen, Jesper 2006. Offertradition og religion i ældre jernalder i Sydskandinavien: Med særlig henblik på bebyggelsesofringer. [The Tradition of Offering and Religion in South Scandinavia in the Early Iron Age: With Special Emphasis on Settlement Offerings.] Kuml: Arbog for Jysk Arkæologisk Selskab. Aarhus: Aarhus Universitetsforlag, pp. 117-175.

Hawkes, Christopher F. 1954. Archaeological Theory and Method: Some Suggestions from the Old World. American Anthropologist, Vol. 56, No. 2, pp. 155-168, doi: 10.1525/aa.1954.56.2.02a00660.

Hukantaival, Sonja 2007. Hare's Feet under a Hearth - Discussing 'Ritual' Deposits in Buildings. In: V. Immonen \& M. Lempiäinen \& U. Rosendahl (ed.) Hortus Novus: Fresh Approaches to Medieval Archaeology in Finland. Archaeologia Medii Aevi Finlandiae XIV. Turku: Suomen Keskiajan Arkeologian Seura, pp. 66-75.

Humphrey, Caroline \& Laidlaw, James 1994. The Archetypal Actions of Ritual: A Theory of Ritual Illustrated by the Jain Rite of Worship. Oxford Studies in Social and Cultural Anthropology. Oxford: Clarendon Press.

Insoll, Timothy (ed.) 2001. Archaeology and World Religion. London \& New York: Routledge.

Insoll, Timothy 2004a. Archaeology, Ritual, Religion. New York: Routledge.

Insoll, Timothy 2004b. Are Archaeologists Afraid of Gods? Some Thoughts on Archaeology and Religion. In: T. Insoll (ed.) Belief in the Past: The Proceedings of the 2002 Manchester Conference on Archaeology and Religion. BAR International Series, Vol. 1212. Oxford: Archaeopress, pp. 1-6.

Insoll, Timothy (ed.) 2009. Special issue: Materiality, Belief, Ritual: Archaeology and Material Religion. Material Religion, Vol. 5, No. 3. Available at http://www. ingentaconnect.com/content/bloomsbury/mar/2009/00000005/00000003;jsession $\mathrm{id}=4 \mathrm{t} 6 \mathrm{~m} 1 \mathrm{fp} 36 \mathrm{ueuk}$.alice, last accessed on December 3, 2013.

Insoll, Timothy 2011a. Ancestor Cults. In: T. Insoll (ed.) The Oxford Handbook of the Archaeology of Ritual and Religion. Oxford \& New York: Oxford University Press, pp. 1043-1058, http://dx.doi.org/10.1093/oxfordhb/9780199232444.013.0066.

Insoll, Timothy (ed.) 2011b. The Oxford Handbook of the Archaeology of Ritual and Religion. Oxford \& New York: Oxford University Press, doi: 10.1093/ oxfordhb/9780199232444.001.0001.

Jaanits, Lembit 1961. Jooni kiviaja uskumustest. [Characteristic Beliefs of the Stone Age.] In: E. Jansen (comp.) Religiooni ja ateismi ajaloost Eestis, Vol. 2. Tallinn: Eesti Riiklik Kirjastus, pp. 5-70.

Jets, Indrek 2001. Mõnda müütide kajastumisest muinas-Eesti ornamentikas. [About the Reflection of Myths in Ancient Estonian Ornamentation.] In: P. Leppik (ed.) Uurimusi mü̈̈dist ja maagiast. Tallinn: Tallinna Pedagoogikaülikooli Kirjastus, pp. 135-144.

Johanson, Kristiina 2009. The Changing Meaning of "Thunderbolts". Folklore: Electronic Journal of Folklore, Vol. 42, pp. 129-174. Available at http://www.folklore.ee/ folklore/vol42/johanson.pdf, last accessed on November 26, 2013.

Jonuks, Tõnno 2005. Archaeology of Religion: Possibilities and Prospects. Estonian Journal of Archaeology, Vol. 9, No. 1, pp. 32-59. 
Jonuks, Tõnno 2007. Holy Groves in Estonian Religion. Estonian Journal of Archaeology, Vol. 11, No. 1, pp. 3-35. Available at http://www.kirj.ee/public/Archaeology/2007/ issue_1/arch-2007-1-1.pdf, last accessed on December 3, 2013.

Jonuks, Tõnno 2009. Eesti muinasusund. [Prehistoric Religions in Estonia.] Dissertationes archaeologiae Universitatis Tartuensis, Vol. 2. Tartu: Tartu Ülikooli Kirjastus. Available at http://hdl.handle.net/10062/9494, last accessed on December 3, 2013.

Jonuks, Tõnno 2011. An Archaeology of Holy Places: Can We Find 'Forgotten' Sacred Sites? Kultūras krustpunkti 5. Rīga: Nordik, pp. 78-88.

Jonuks, Tõnno 2013. An Antler Object from the Pärnu River: An Axe, a God or a Decoy? In: K. Johanson \& M. Tõrv (eds.) Man, His Time, Artefacts, and Places. Collection of articles dedicated to Richard Indreko. Muinasaja teadus, Vol. 19. Tartu: University of Tartu, pp. 225-246.

Jonuks, Tõnno \& Friedenthal, Meelis \& Haak, Arvi 2010. Värtnakeder, talisman või nõiaese - märkidega kiviketas Viljandimaalt Rattama talust. [A Spindle Whorl, a Talisman or a Witchcraft Object: A Stone Disc Marked with Symbols from Rattama Farm in Viljandimaa.] In: Ü. Tamla (ed.) Ilusad asjad. Tähelepanuväärseid leide Eesti arheoloogiakogudest. Muinasaja teadus, Vol. 21. Tallinn: Tallinna Ülikooli Ajaloo Instituut, pp. 269-286.

Jonuks, Tõnno \& Joosu, Lauri 2013. Pendants of St. Anthony Cross with the Crucifixion from Estonia: Possible Badges of a Folk Pilgrimage. Estonian Journal of Archaeology, Vol. 17, No. 2, pp. 123-138, doi: 10.3176/arch.2013.2.02.

Kaliff, Anders 2005. The Grave as Concept and Phenomenon: Reflections on the Relation between Archaeological Terminology and Interpretation. In: T. Artelius \& F. Svanberg (eds.) Dealing with the Dead: Archaeological Perspectives on Prehistoric Scandinavian Burial Ritual. Ödeshög: The Swedish National Heritage Board, pp. 125-142.

Kaul, Flemming 1998. Ships on Bronzes. A Study in Bronze Age Religion and Iconography. PNM Studies in Archaeology \& History, Vol. 3, No. 1. Copenhagen: National Museum of Denmark.

Kertzer, David I. 1988. Ritual, Politics, and Power. New Haven, CT: Yale University Press.

Kristiansen, Kristian \& Larsson, Thomas B. 2005. The Rise of Bronze Age Society. Travels, Transmissions and Transformations. Cambridge: Cambridge University Press.

Kulmar, Tarmo 1992. Eesti muinasusundi hingefenomenoloogiast. III: Hingekujutlused Eesti kiviaja arheoloogiaaineses. [On Phenomenology of Soul in Ancient Estonian Religion. III: Reflections of the Notions of Soul in Stone Age Archaeological Finds in Estonia.] Akadeemia, Vol. 9, pp. 1870-1887.

Kurisoo, Tuuli 2012. Ristripatsid Eesti 12.-13. sajandi laibakalmistutes: kas ehted või usu tunnused? [Cross-Shaped Pendants in the 12th-13th-Century Inhumation Burials: Adornments or Signs of Belief?] Õpetatud Eesti Seltsi aastaraamat, pp. 213-234. Available at http://www.ut.ee/OES/wp-content/uploads/Kurisoo.pdf, last accessed on October 3, 2013.

Kurisoo, Tuuli 2013. Hilisrauaaegsed ristripatsid ja ristimärgiga rinnalehed Eestis. [Latest Iron Age Cross Pendants and Silver Round Pendants with a Cross 
Motif from Estonia.] Master's thesis. Tartu: Tartu Ülikool, Ajaloo ja arheoloogia instituut. Available at: http://www.arheo.ut.ee/docs/MA13_Kurisoo.pdf, last accessed on November 25, 2013.

Kyriakidis, Evangelos (ed.) 2007. The Archaeology of Ritual. Los Angeles: Cotsen Institute of Archaeology.

Lang, Valter 1999. Kultuurmaastikku luues. Essee maastiku religioossest ja sümboliseeritud korraldusest. [Creating the Cultural Landscape: An Essay on Religious and Symbolic Organisation of the Landscape.] Eesti Arheoloogiaajakiri, Vol. 3. No. 1, pp. 63-85.

Lewis, Gilbert 1980. Day of Shining Red: An Essay on Understanding Ritual. Cambridge: Cambridge University Press.

Lewis-Williams David \& Clottes Jean 1998. The Shamans of Prehistory: Trance and Magic in the Painted Caves. New York: Harry N. Abrams.

Lewis-Williams David J. \& Dowson, Thomas A. 1988. The Signs of All Times: Entoptic Phenomena in Upper Palaeolithic Art. Current Anthropology, Vol. 29, No. 2, pp. 201-245. Available at http://www.jstor.org/discover/10.2307/2743395?uid=3 $737920 \&$ uid $=2134 \&$ uid $=2 \&$ uid $=70 \&$ uid $=4 \&$ sid $=21103031512791$, last accessed on December 3, 2013.

Meskell, Lynn 2004. Divine Things. In: Elizabeth DeMarrais \& Chris Gosden \& Colin Renfrew (eds.) Rethinking Materiality: The Engagement of Mind with the Material World. McDonald Institute Monographs. Cambridge: McDonald Institute for Archaeological Research, pp. 249-259.

Moore, Sally F. \& Myerhoff, Barbara G. (eds.) 1977. Secular Ritual. Assen: Van Gorcum.

Morgan, David (ed.) 2010. Religion and Material Culture: The Matter of Belief. London \& New York: Routledge.

Oras, Ester 2010. Ritual Wealth Deposits in Estonian Middle Iron Age Material. Estonian Journal of Archaeology, Vol. 14, No. 2, pp. 123-142, http://dx.doi.org/10.3176/ arch.2010.2.02.

Oras, Ester, forthcoming a. East Baltic Middle Iron Age Wealth Deposits in Burial Areas: An Example of Regional Cultural Practice. Archaeologia Baltica, Vol 19.

Oras, Ester, forthcoming b. Practices of Wealth Depositing in the 1st-9th-Century AD Eastern Baltic. Doctoral dissertation. Division of Archaeology, University of Cambridge.

Osborne, Robin 2004. Hoards, Votives, Offerings: The Archaeology of the Dedicated Object. World Archaeology, Vol. 36, No. 1, pp. 1-10, http://dx.doi.org/10.1080/00 43824042000192696.

Pollard, Josh 2009. The Materialization of Religious Structures in the Time of Stonehenge. Material Religion: The Journal of Objects, Art and Belief, Vol. 5, No. 3, pp. 332-353, http://dx.doi.org/10.2752/175183409X12550007729987.

Price, Niel S. 2001. The Archaeology of Shamanism. London: Routledge.

Price, Niel S. 2002. The Viking Way: Religion and War in Late Iron Age Scandinavia. Aun, Vol. 31. Uppsala: Department of Archaeology and Ancient History, Uppsala University.

Randsborg, Klavs 1993. Kivik Archaeology \& Iconography. Acta Archaeologica, Vol. 64, No.1. København: Munksgaard. 
Renfrew, Colin 1985. The Archaeology of Cult: The Sanctuary at Phylakopi. London: British School of Archaeology at Athens.

Renfrew, Colin 1994. The Archaeology of Religion. In: C. Renfrew \& E. Zubrow (eds.) The Ancient Mind: Elements of Cognitive Archaeology. Cambridge: Cambridge University Press, pp. 47-54, http://dx.doi.org/10.1017/CBO9780511598388.007.

Rowlands, Michael 2004. The Materiality of Sacred Power. In: Elizabeth DeMarrais \& Chris Gosden \& Colin Renfrew (eds.) Rethinking Materiality: The Engagement of Mind with the Material World. McDonald Institute Monographs. Cambridge: McDonald Institute for Archaeological Research, pp. 197-203.

Sørensen, Jesper 2005. Charisma, Tradition and Ritual: A Cognitive Approach to Magical Agency. In: H. Whitehouse \& R.N. McCauley (eds.) Mind and Religion: Psychological and Cognitive Foundations of Religiosity. Walnut Creek, CA: AltaMira Press, pp. 167-185.

Tamla, Toomas 1985. Kultuslikud allikad Eestis. [Cult Springs in Estonia.] In: Rahvasuust kirjapanekuni. Uurimusi rahvaluule proosaloomingust ja kogumisloost. Eesti NSV Teaduste Akadeemia Emakeele Seltsi Toimetised, Vol. 17, pp. 122-146.

The Concise Oxford Dictionary of Archaeology 2008. Timothy Darvill (ed.). Oxford University Press. Oxford Reference Online, available at http://www.oxfordreference. com/views/ENTRY.html?subview=Main\&entry=t102.e3642, last accessed on October 16, 2013.

The Concise Oxford Dictionary of World Religions 2000. John Bowker (ed.). Oxford University Press. Oxford Reference Online, available at http://www.oxfordreference. com/views/ENTRY.html?subview=Main\&entry=t101.e6210, last accessed on October 16, 2013.

Turner, Victor 1967. The Forest of Symbols: Aspects of Ndembu Ritual. Ithaca, N.Y.: Cornell University Press.

Tylor, Edward B. 1929 [1871]. Primitive Culture: Researches into the Development of Mythology, Philosophy, Religion, Language, Art, and Custom. 5th reprint. London: John Murray.

Urtāns, Juris 2008. Ancient Cult Sites of Semigallia = Zemgales Senās Kulta Vietas. Riga: Nordik.

Valk, Heiki 1994. The Reflection of Pre-Christian Beliefs in the Estonian Medieval and Post-Medieval Village Cemeteries. Mitteilungen für Anthropologie und Religionsgeschichte, Vol. 8. Münster: Ugarit Verlag, pp. 177-189.

Valk, Heiki 2001 [1999]. Rural Cemeteries of Southern Estonia 1225-1800 AD. CCC Papers 3. Visby: Gotland University College Centre for Baltic Studies; Tartu: University of Tartu, Archaeology Centre.

Vaitkevičius, Vykintas 2004. Studies into the Balts' Sacred Places. BAR International Series, Vol. 1228. Oxford: John and Erica Hedges Ltd.

Vedru, Gurly 2011. Põhja-Eesti arheoloogilised maastikud / Archaeological Landscapes of North Estonia. Dissertationes archaeologica Universitatis Tartuensis 3. Tartu: Tartu University Press. Available at http://dspace.utlib.ee/dspace/bitstream/ handle/10062/16297/vedru_gurly.pdf?sequence=1, last accessed on November $26,2013$.

Verhoeven, Marc 2011. The Many Dimensions of Ritual. In: T. Insoll (ed.) The Oxford Handbook of the Archaeology of Ritual and Religion. Oxford \& New 
York: Oxford University Press, pp. 115-132, http://dx.doi.org/10.1093/ oxfordhb/9780199232444.013.0010.

Wesler, Kit W. 2012. An Archaeology of Religion. Lanham \& Boulder \& New York \& Toronto \& Plymouth: University Press of America.

Whitehouse, Harvey. 2004. Modes of Religiosity: A Cognitive Theory of Religious Transmission. Walnut Creek \& Lanham \& New York \& Toronto \& Oxford: Altamira Press.

Whitley, David S. 2005. Introduction to Rock Art Research. Walnut Creek, CA: Left Coast Press.

Wax, Murray \& Wax, Rosalie 1962. The Magical World View. Journal for the Scientific Study of Religion, Vol. 1, No. 2, pp. 179-188, http://dx.doi.org/10.2307/1384696. 